\title{
Molecular Mechanisms Of Oncogenesis Through The Lens Of Nucleosomes And Histones
}

Daniel Espiritu1\#, Anna K. Gribkova²,3\#, Shubhangi Gupta ${ }^{1}$, Alexey K. Shaytan ${ }^{2,3,4^{*}}$ and Anna R. Panchenko ${ }^{1 *}$

\# - authors contributed equally

1Department of Pathology and Molecular Medicine, School of Medicine, Queen's University, ON, Canada

2Department of Biology, Lomonosov Moscow State University, 1-12 Leninskie Gory, Moscow, 119991, Russia

${ }^{3}$ Sirius University of Science and Technology, 1 Olympic Ave, Sochi, 354340, Russia

${ }^{4}$ Bioinformatics Lab, Faculty of Computer Science, HSE University, 11 Pokrovsky boulvar, Moscow, Russia 109028

*-corresponding authors: anna.panchenko@queensu.ca, shaytan ak@mail.bio.msu.ru

\section{$\underline{\text { Supplementary Information }}$}

Table S1 The role in development and involvement in cancer of some known pioneer transcription factors.

\begin{tabular}{|c|c|c|}
\hline $\begin{array}{l}\text { Pioneer } \\
\text { Transcription } \\
\text { Factor }\end{array}$ & Role in development & Associated cancer types \\
\hline FOXA1 1-2 & $\begin{array}{l}\text { Modulates transcriptional activity } \\
\text { of nuclear receptors, development } \\
\text { of endoderm-derived tissues }\end{array}$ & Breast cancer and prostate cancer ${ }^{3-5}$ \\
\hline FOXA2 ${ }^{2}$ & $\begin{array}{l}\text { Embryonic and endoderm-derived } \\
\text { tissues development }\end{array}$ & $\begin{array}{l}\text { Cancers of ovary }{ }^{6} \text {, lung }{ }^{7-8} \text {, liver }{ }^{9} \text {, } \\
\text { pancreas }{ }^{10} \text {, colon }{ }^{11} \text {, breast }{ }^{12} \text { and } \\
\text { cervix }{ }^{13}\end{array}$ \\
\hline GATA2 1 & $\begin{array}{l}\text { Regulates gene expression in } \\
\text { epithelial cells }\end{array}$ & $\begin{array}{l}\text { Leukemia }{ }^{14} \text { and prostate cancer } \\
17\end{array}$ \\
\hline CEBPA $^{18}$ & Development of lung and liver & $\begin{array}{l}\text { Gastric cancer }{ }^{19} \text { and acute myeloid } \\
\text { leukemia } 20\end{array}$ \\
\hline
\end{tabular}




\begin{tabular}{|c|c|c|}
\hline GATA4 21-22 & Cardiac and testicular development & $\begin{array}{l}\text { Lung }{ }^{23} \text {, gastric }{ }^{24}, \text { colorectal }{ }^{24} \text { and } \\
\text { pancreas cancers }{ }^{25}\end{array}$ \\
\hline KLF4 $^{1}$ & $\begin{array}{l}\text { Gene activator and repressor and } \\
\text { maintenance of embryonic cell }\end{array}$ & $\begin{array}{l}\text { Gastric cancer }{ }^{26} \text {, breast cancer }{ }^{27} \\
\text { and drug-resistant colon cancer }{ }^{28}\end{array}$ \\
\hline GATA3 29 & $\begin{array}{l}\text { Regulates } \mathrm{T} \text { cell expression of } \mathrm{T} \\
\text { cell receptor gene }{ }^{30}\end{array}$ & Breast cancer ${ }^{31-32}$ \\
\hline FOXD3 ${ }^{33}$ & $\begin{array}{l}\text { Gene activator and repressor; } \\
\text { neural crest cell development }\end{array}$ & $\begin{array}{l}\text { Colorectal cancer }{ }^{34} \text { and lung cancer } \\
35-36\end{array}$ \\
\hline BRN2 ${ }^{21}$ & Neuronal differentiation & Prostate cancer ${ }^{37-39}$ \\
\hline PBX1 40 & $\begin{array}{l}\text { Sexual development and } \\
\text { differentiation }\end{array}$ & $\begin{array}{l}\text { Breast cancer }{ }^{41} \text { Androgen- } \\
\text { independent prostate cancer }{ }^{42}\end{array}$ \\
\hline HAND2 21 & $\begin{array}{l}\text { Limb development and cardiac } \\
\text { morphogenesis }\end{array}$ & $\begin{array}{l}\text { Cervical cancer }{ }^{43} \text { and colorectal } \\
\text { cancer }{ }^{44}\end{array}$ \\
\hline SOX ${ }^{1}$ & Embryonic development & Squamous cell carcinoma ${ }^{45}$ \\
\hline PAX7 21,46 & $\begin{array}{l}\text { Maintenance of muscle satellite } \\
\text { cells }\end{array}$ & $\begin{array}{l}\text { Ewing sarcoma }{ }^{47} \text { and alveolar } \\
\text { rhabdomyosarcoma } 48\end{array}$ \\
\hline TBX5 ${ }^{21}$ & Heart and limb development & $\begin{array}{l}\text { Colorectal cancer }{ }^{49} \text { and lung cancer } \\
50\end{array}$ \\
\hline ASCL1 46 & $\begin{array}{l}\text { Neuronal differentiation and } \\
\text { development of neural lineages in } \\
\text { CNS }\end{array}$ & Small cell lung carcinoma ${ }^{51}$ \\
\hline PU.1 ${ }^{46}$ & $\begin{array}{l}\begin{array}{l}\text { Activation of B-cells or } \\
\text { macrophages }\end{array} \\
\end{array}$ & $\begin{array}{l}\text { Acute myeloid leukemia } 52 \text { and } \\
\text { breast cancer } 53\end{array}$ \\
\hline TP53 46, 54 & $\begin{array}{l}\text { Tumor suppressor in many cancer } \\
\text { types }\end{array}$ & $\begin{array}{l}\text { Breast cancer, ovarian cancer }{ }^{55} \text { and } \\
\text { pancreatic cancer } 56\end{array}$ \\
\hline OCT4 1,46 & Expressed in pluripotent stem cells & $\begin{array}{l}\text { Testicular germ cell tumor Breast } \\
\text { cancer } 57\end{array}$ \\
\hline EBF1 ${ }^{46,58}$ & $\begin{array}{l}\text { Essential maintenance of } \mathrm{B} \text { cell } \\
\text { identity } 59\end{array}$ & $\begin{array}{l}\text { Gastric cancer }{ }^{60} \text { and acute } \\
\text { lymphoblastic leukemia }{ }^{61} \text {. }\end{array}$ \\
\hline ESRRB ${ }^{46,62}$ & $\begin{array}{l}\text { Self-renewal in embryonic stem } \\
\text { cells } 63\end{array}$ & $\begin{array}{l}\text { Bladder, prostate and colon tumors } \\
64 \text { and breast cancer } 65\end{array}$ \\
\hline NEUROD1 46, 66 & $\begin{array}{l}\text { Promotes neuronal differentiation, } \\
\text { dendrite morphogenesis, and } \\
\text { cerebellar cortex maintenance }\end{array}$ & $\begin{array}{l}\text { Colorectal cancer }{ }^{67} \text {, small-cell lung } \\
\text { cancer and other neuroendocrine } \\
\text { tumors } 68-69\end{array}$ \\
\hline HNF1A ${ }^{21-22}$ & $\begin{array}{llll}\text { Tissue specific } & \text { expression } & \text { of } \\
\text { various genes, especially } & \text { in } \\
\text { pancreas and liver } & & \end{array}$ & $\begin{array}{l}\text { Gastric cancer }{ }^{70} \text {, bladder cancer }{ }^{71} \\
\text { and cervical cancer }{ }^{72}\end{array}$ \\
\hline
\end{tabular}




\section{References:}

(1) Zaret, K. S.; Carroll, J. S. Pioneer Transcription Factors: Establishing Competence for Gene Expression. Genes Dev. 2011, 25, 2227-2241.

(2) Whirledge, S.; Kisanga, E. P.; Taylor, R. N.; Cidlowski, J. A. Pioneer Factors Foxal and Foxa2 Assist Selective Glucocorticoid Receptor Signaling in Human Endometrial Cells. Endocrinology 2017, 158, 4076-4092.

(3) Sahu, B.; Laakso, M.; Ovaska, K.; Mirtti, T.; Lundin, J.; Rannikko, A.; Sankila, A.; Turunen, J. P.; Lundin, M.; Konsti, J. et al. Dual Role of Foxa1 in Androgen Receptor Binding to Chromatin, Androgen Signalling and Prostate Cancer. EMBO J. 2011, 30, 3962-3976.

(4) Thorat, M. A.; Marchio, C.; Morimiya, A.; Savage, K.; Nakshatri, H.; Reis-Filho, J. S.; Badve, S. Forkhead Box A1 Expression in Breast Cancer Is Associated with Luminal Subtype and Good Prognosis. J. Clin. Pathol. 2008, 61, 327.

(5) Golson, M. L.; Kaestner, K. H. Fox Transcription Factors: From Development to Disease. Development 2016, 143, 4558-4570.

(6) Salem, M.; O'Brien, J. A.; Bernaudo, S.; Shawer, H.; Ye, G.; Brkić, J.; Amleh, A.; Vanderhyden, B. C.; Refky, B.; Yang, B. B. et al. Mir-590-3p Promotes Ovarian Cancer Growth and Metastasis Via a Novel Foxa2-Versican Pathway. Cancer Res. 2018, 78, 4175-4190.

(7) Camolotto, S. A.; Pattabiraman, S.; Mosbruger, T. L.; Jones, A.; Belova, V. K.; Orstad, G.; Streiff, M.; Salmond, L.; Stubben, C.; Kaestner, K. H. et al. Foxa1 and Foxa2 Drive Gastric Differentiation and Suppress Squamous Identity in Nkx2-1-Negative Lung Cancer. eLife 2018, 7.

(8) Dhamija, S.; Becker, A. C.; Sharma, Y.; Myacheva, K.; Seiler, J.; Diederichs, S. Linc00261 and the Adjacent Gene Foxa2 Are Epithelial Markers and Are Suppressed During Lung Cancer Tumorigenesis and Progression. Noncoding RNA 2018, 5.

(9) Li, Z.; Tuteja, G.; Schug, J.; Kaestner, K. H. Foxa1 and Foxa2 Are Essential for Sexual Dimorphism in Liver Cancer. Cell 2012, 148, $72-83$.

(10) Bailey, P.; Chang, D. K.; Nones, K.; Johns, A. L.; Patch, A. M.; Gingras, M. C.; Miller, D. K.; Christ, A. N.; Bruxner, T. J.; Quinn, M. C. et al. Genomic Analyses Identify Molecular Subtypes of Pancreatic Cancer. Nature 2016, 531, 47-52.

(11) Wang, B.; Liu, G.; Ding, L.; Zhao, J.; Lu, Y. Foxa2 Promotes the Proliferation, Migration and Invasion, and Epithelial Mesenchymal Transition in Colon Cancer. Exp. Ther. Med. 2018, 16, 133-140.

(12) Cao, J.; Wang, X.; Wang, D.; Ma, R.; Li, X.; Feng, H.; Wang, J.; Liu, S.; Wang, L. Pgc$1 \beta$ Cooperating with Foxa2 Inhibits Proliferation and Migration of Breast Cancer Cells. Cancer. Cell. Int. 2019, 19, 93.

(13) Zhan, F.; Zhong, Y.; Qin, Y.; Li, L.; Wu, W.; Yao, M. Snd1 Facilitates the Invasion and Migration of Cervical Cancer Cells by Smurf1-Mediated Degradation of Foxa2. Exp. Cell Res. 2020, 388, 111809.

(14) Zhang, S. J.; Ma, L. Y.; Huang, Q. H.; Li, G.; Gu, B. W.; Gao, X. D.; Shi, J. Y.; Wang, Y. Y.; Gao, L.; Cai, X. et al. Gain-of-Function Mutation of Gata-2 in Acute Myeloid Transformation of Chronic Myeloid Leukemia. Proc. Natl. Acad. Sci. U. S. A. 2008, 105, 2076-2081. 
(15) Wang, Q.; Li, W.; Liu, X. S.; Carroll, J. S.; Jänne, O. A.; Keeton, E. K.; Chinnaiyan, A. M.; Pienta, K. J.; Brown, M. A Hierarchical Network of Transcription Factors Governs Androgen Receptor-Dependent Prostate Cancer Growth. Mol. Cell 2007, 27, 380-392.

(16) Robinson, J. L.; Tzou, K. S.; Parker, A. S.; Heckman, M. G.; Wu, K. J.; Hilton, T. W.; Pisansky, T. M.; Schild, S. E.; Peterson, J. L.; Vallow, L. A. et al. Gata2 Expression and Biochemical Recurrence Following Salvage Radiation Therapy for Relapsing Prostate Cancer. Br. J. Radiol. 2017, 90, 20170174.

(17) Rodriguez-Bravo, V.; Carceles-Cordon, M.; Hoshida, Y.; Cordon-Cardo, C.; Galsky, M. D.; Domingo-Domenech, J. The Role of Gata2 in Lethal Prostate Cancer Aggressiveness. Nat. Rev. Urol. 2017, 14, 38-48.

(18) van Oevelen, C.; Collombet, S.; Vicent, G.; Hoogenkamp, M.; Lepoivre, C.; Badeaux, A.; Bussmann, L.; Sardina, Jose L.; Thieffry, D.; Beato, M. et al. C/Ebp $\alpha$ Activates PreExisting and De Novo Macrophage Enhancers During Induced Pre-B Cell Transdifferentiation and Myelopoiesis. Stem Cell Rep. 2015, 5, 232-247.

(19) Ke, D.; Li, H.; Zhang, Y.; An, Y.; Fu, H.; Fang, X.; Zheng, X. The Combination of Circulating Long Noncoding Rnas Ak001058, Inhba-As1, Mir4435-2hg, and Cebpa-As1 Fragments in Plasma Serve as Diagnostic Markers for Gastric Cancer. Oncotarget 2017, 8, 21516-21525.

(20) Mannelli, F.; Ponziani, V.; Bencini, S.; Bonetti, M. I.; Benelli, M.; Cutini, I.; Gianfaldoni, G.; Scappini, B.; Pancani, F.; Piccini, M. et al. Cebpa-Double-Mutated Acute Myeloid Leukemia Displays a Unique Phenotypic Profile: A Reliable Screening Method and Insight into Biological Features. Haematologica 2017, 102, 529-540.

(21) Iwafuchi-Doi, M.; Zaret, K. S. Pioneer Transcription Factors in Cell Reprogramming. Genes Dev. 2014, 28, 2679-2692.

(22) Huang, P.; He, Z.; Ji, S.; Sun, H.; Xiang, D.; Liu, C.; Hu, Y.; Wang, X.; Hui, L. Induction of Functional Hepatocyte-Like Cells from Mouse Fibroblasts by Defined Factors. Nature 2011, 475, 386-389.

(23) Gao, L.; Hu, Y.; Tian, Y.; Fan, Z.; Wang, K.; Li, H.; Zhou, Q.; Zeng, G.; Hu, X.; Yu, L. et al. Lung Cancer Deficient in the Tumor Suppressor Gata4 Is Sensitive to Tgfbr1 Inhibition. Nat. Commun. 2019, 10, 1665.

(24) Akiyama, Y.; Watkins, N.; Suzuki, H.; Jair, K. W.; van Engeland, M.; Esteller, M.; Sakai, H.; Ren, C. Y.; Yuasa, Y.; Herman, J. G. et al. Gata-4 and Gata-5 Transcription Factor Genes and Potential Downstream Antitumor Target Genes Are Epigenetically Silenced in Colorectal and Gastric Cancer. Mol. Cell Biol. 2003, 23, 8429-8439.

(25) Gong, Y.; Zhang, L.; Zhang, A.; Chen, X.; Gao, P.; Zeng, Q. Gata4 Inhibits Cell Differentiation and Proliferation in Pancreatic Cancer. PLoS One 2018, 13, e0202449e0202449.

(26) Zhang, J.; Zhu, Z.; Wu, H.; Yu, Z.; Rong, Z.; Luo, Z.; Xu, Y.; Huang, K.; Qiu, Z.; Huang, C. Podxl, Negatively Regulated by Klf4, Promotes the Emt and Metastasis and Serves as a Novel Prognostic Indicator of Gastric Cancer. Gastric Cancer 2019, 22, 4859.

(27) Jia, Y.; Zhou, J.; Luo, X.; Chen, M.; Chen, Y.; Wang, J.; Xiong, H.; Ying, X.; Hu, W.; Zhao, W. et al. Klf4 Overcomes Tamoxifen Resistance by Suppressing Mapk Signaling Pathway and Predicts Good Prognosis in Breast Cancer. Cell Signal. 2018, 42, 165-175. 
(28) Yadav, S. S.; Kumar, M.; Varshney, A.; Yadava, P. K. Klf4 Sensitizes the Colon Cancer Cell Hct-15 to Cisplatin by Altering the Expression of Hmgb1 and Htert. Life Sci. 2019, 220, 169-176.

(29) Tanaka, H.; Takizawa, Y.; Takaku, M.; Kato, D.; Kumagawa, Y.; Grimm, S. A.; Wade, P. A.; Kurumizaka, H. Interaction of the Pioneer Transcription Factor Gata3 with Nucleosomes. Nat. Commun. 2020, 11, 4136.

(30) Ho, I. C.; Vorhees, P.; Marin, N.; Oakley, B. K.; Tsai, S. F.; Orkin, S. H.; Leiden, J. M. Human Gata-3: A Lineage-Restricted Transcription Factor That Regulates the Expression of the T Cell Receptor Alpha Gene. EMBO J. 1991, 10, 1187-1192.

(31) Lin, H. Y.; Zeng, D.; Liang, Y. K.; Wei, X. L.; Chen, C. F. Gata3 and Trps1 Are Distinct Biomarkers and Prognostic Factors in Breast Cancer: Database Mining for Gata Family Members in Malignancies. Oncotarget 2017, 8, 34750-34761.

(32) Tozbikian, G. H.; Zynger, D. L. A Combination of Gata3 and Sox10 Is Useful for the Diagnosis of Metastatic Triple-Negative Breast Cancer. Hum. Pathol. 2019, 85, 221-227. Lukoseviciute, M.; Gavriouchkina, D.; Williams, R. M.; Hochgreb-Hagele, T.; Senanayake, U.; Chong-Morrison, V.; Thongjuea, S.; Repapi, E.; Mead, A.; SaukaSpengler, T. From Pioneer to Repressor: Bimodal Foxd3 Activity Dynamically Remodels Neural Crest Regulatory Landscape In vivo. Dev. Cell 2018, 47, 608-628.e606.

(34) Hauptman, N.; Jevšinek Skok, D.; Spasovska, E.; Boštjančič, E.; Glavač, D. Genes Cep55, Foxd3, Foxf2, Gnao1, Gria4, and Kcna5 as Potential Diagnostic Biomarkers in Colorectal Cancer. BMC Med. Genomics 2019, 12, 54.

(35) Xu, W.; Li, J.; Li, L.; Hou, T.; Cai, X.; Liu, T.; Yang, X.; Wei, H.; Jiang, C.; Xiao, J. Foxd3 Suppresses Tumor-Initiating Features in Lung Cancer Via Transcriptional Repression of Wdr5. Stem Cells 2019, 37, 582-592.

(36) Yan, J. H.; Zhao, C. L.; Ding, L. B.; Zhou, X. Foxd3 Suppresses Tumor Growth and Angiogenesis in Non-Small Cell Lung Cancer. Biochem. Biophys. Res. Commun. 2015, 466, 111-116.

(37) Fenner, A. Prostate Cancer: Brn2 Is a Neuroendocrine Driver. Nat. Rev. Urol. 2017, 14, 10.

(38) Bishop, J. L.; Thaper, D.; Vahid, S.; Davies, A.; Ketola, K.; Kuruma, H.; Jama, R.; Nip, K. M.; Angeles, A.; Johnson, F. et al. The Master Neural Transcription Factor Brn2 Is an Androgen Receptor-Suppressed Driver of Neuroendocrine Differentiation in Prostate Cancer. Cancer Discov. 2017, 7, 54-71.

(39) Bhagirath, D.; Yang, T. L.; Tabatabai, Z. L.; Majid, S.; Dahiya, R.; Tanaka, Y.; Saini, S. Brn4 Is a Novel Driver of Neuroendocrine Differentiation in Castration-Resistant Prostate Cancer and Is Selectively Released in Extracellular Vesicles with Brn2. Clin. Cancer Res. 2019, 25, 6532-6545.

(40) A Pioneer Role for Pbx1 in Neurogenesis. Development 2016, 143, e1301.

(41) Wang, J.; Shidfar, A.; Ivancic, D.; Ranjan, M.; Liu, L.; Choi, M. R.; Parimi, V.; Gursel, D. B.; Sullivan, M. E.; Najor, M. S. et al. Overexpression of Lipid Metabolism Genes and Pbx1 in the Contralateral Breasts of Women with Estrogen Receptor-Negative Breast Cancer. Int. J. Cancer 2017, 140, 2484-2497.

(42) Kikugawa, T.; Kinugasa, Y.; Shiraishi, K.; Nanba, D.; Nakashiro, K.; Tanji, N.; Yokoyama, M.; Higashiyama, S. Plzf Regulates Pbx1 Transcription and Pbx1-Hoxc8 Complex Leads to Androgen-Independent Prostate Cancer Proliferation. Prostate 2006, 66, 1092-1099. 
(43) Chen, S.; Wang, J. Hand2-As1 Inhibits Invasion and Metastasis of Cervical Cancer Cells Via Microrna-330-5p-Mediated Ldoc1. Cancer. Cell. Int. 2019, 19, 353.

(44) Zhou, J.; Lin, J.; Zhang, H.; Zhu, F.; Xie, R. Lncrna Hand2-As1 Sponging Mir-1275 Suppresses Colorectal Cancer Progression by Upregulating Klf14. Biochem. Biophys. Res. Commun. 2018, 503, 1848-1853.

(45) Boumahdi, S.; Driessens, G.; Lapouge, G.; Rorive, S.; Nassar, D.; Le Mercier, M.; Delatte, B.; Caauwe, A.; Lenglez, S.; Nkusi, E. et al. Sox2 Controls Tumour Initiation and Cancer Stem-Cell Functions in Squamous-Cell Carcinoma. Nature 2014, 511, 246250.

(46) Mayran, A.; Drouin, J. Pioneer Transcription Factors Shape the Epigenetic Landscape. $J$. Biol. Chem. 2018, 293, 13795-13804.

(47) Toki, S.; Wakai, S.; Sekimizu, M.; Mori, T.; Ichikawa, H.; Kawai, A.; Yoshida, A. Pax7 Immunohistochemical Evaluation of Ewing Sarcoma and Other Small Round Cell Tumours. Histopathology 2018, 73, 645-652.

(48) Galili, N.; Davis, R. J.; Fredericks, W. J.; Mukhopadhyay, S.; Rauscher, F. J.; Emanuel, B. S.; Rovera, G.; Barr, F. G. Fusion of a Fork Head Domain Gene to Pax3 in the Solid Tumour Alveolar Rhabdomyosarcoma. Nat. Genet. 1993, 5, 230-235.

(49) Dong, M. J.; Zhou, Y.; Duan, M.; Gao, Q. M.; Zhao, J. H. [Clinical Significance and Mechanism of Tbx5 Gene in Colorectal Cancer]. Zhonghua Zhong Liu Za Zhi 2020, 42, 383-390.

(50) Xiong, Y.; Zhang, X.; Lin, Z.; Xiong, A.; Xie, S.; Liang, J.; Zhang, W. Sfta1p, Linc00968, Gata6-As1, Tbx5-As1, and Fezf1-As1 Are Crucial Long Non-Coding Rnas Associated with the Prognosis of Lung Squamous Cell Carcinoma. Oncol. Lett. 2019, 18, 3985-3993.

(51) Meder, L.; König, K.; Ozretić, L.; Schultheis, A. M.; Ueckeroth, F.; Ade, C. P.; Albus, K.; Boehm, D.; Rommerscheidt-Fuss, U.; Florin, A. et al. Notch, Asc11, P53 and Rb Alterations Define an Alternative Pathway Driving Neuroendocrine and Small Cell Lung Carcinomas. International journal of cancer 2016, 138, 927-938.

(52) Antony-Debré, I.; Paul, A.; Leite, J.; Mitchell, K.; Kim, H. M.; Carvajal, L. A.; Todorova, T. I.; Huang, K.; Kumar, A.; Farahat, A. A. et al. Pharmacological Inhibition of the Transcription Factor Pu.1 in Leukemia. J. Clin. Investig. 2017, 127, 4297-4313.

(53) Lin, J.; Liu, W.; Luan, T.; Yuan, L.; Jiang, W.; Cai, H.; Yuan, W.; Wang, Y.; Zhang, Q.; Wang, L. High Expression of Pu.1 Is Associated with Her-2 and Shorter Survival in Patients with Breast Cancer. Oncol. Lett. 2017, 14, 8220-8226.

(54) Sammons, M. A.; Zhu, J.; Drake, A. M.; Berger, S. L. Tp53 Engagement with the Genome Occurs in Distinct Local Chromatin Environments Via Pioneer Factor Activity. Genome Res. 2015, 25, 179-188.

(55) Silwal-Pandit, L.; Langerød, A.; Børresen-Dale, A. L. Tp53 Mutations in Breast and Ovarian Cancer. Cold Spring Harb. Perspect. Med. 2017, 7.

(56) Ercan, G.; Karlitepe, A.; Ozpolat, B. Pancreatic Cancer Stem Cells and Therapeutic Approaches. Anticancer Res. 2017, 37, 2761-2775.

(57) Cho, Y.; Kang, H. G.; Kim, S. J.; Lee, S.; Jee, S.; Ahn, S. G.; Kang, M. J.; Song, J. S.; Chung, J. Y.; Yi, E. C. et al. Post-Translational Modification of Oct4 in Breast Cancer Tumorigenesis. Cell Death Differ. 2018, 25, 1781-1795. 
(58) Boller, S.; Ramamoorthy, S.; Akbas, D.; Nechanitzky, R.; Burger, L.; Murr, R.; Schübeler, D.; Grosschedl, R. Pioneering Activity of the C-Terminal Domain of Ebf1 Shapes the Chromatin Landscape for B Cell Programming. Immunity 2016, 44, 527-541. Nechanitzky, R.; Akbas, D.; Scherer, S.; Györy, I.; Hoyler, T.; Ramamoorthy, S.; Diefenbach, A.; Grosschedl, R. Transcription Factor Ebf1 Is Essential for the Maintenance of B Cell Identity and Prevention of Alternative Fates in Committed Cells. Nat. Immunol. 2013, 14, 867-875.

(60) Xing, M.; Ooi, W. F.; Tan, J.; Qamra, A.; Lee, P. H.; Li, Z.; Xu, C.; Padmanabhan, N.; Lim, J. Q.; Guo, Y. A. et al. Genomic and Epigenomic Ebf1 Alterations Modulate Tert Expression in Gastric Cancer. J. Clin. Investig. 2020, 130, 3005-3020.

(61) Mullighan, C. G.; Goorha, S.; Radtke, I.; Miller, C. B.; Coustan-Smith, E.; Dalton, J. D.; Girtman, K.; Mathew, S.; Ma, J.; Pounds, S. B. et al. Genome-Wide Analysis of Genetic Alterations in Acute Lymphoblastic Leukaemia. Nature 2007, 446, 758-764.

(62) Adachi, K.; Kopp, W.; Wu, G.; Heising, S.; Greber, B.; Stehling, M.; Araúzo-Bravo, M. J.; Boerno, S. T.; Timmermann, B.; Vingron, M. et al. Esrrb Unlocks Silenced Enhancers for Reprogramming to Naive Pluripotency. Cell Stem Cell 2018, 23, 266-275 e266.

(63) Latos, P. A.; Goncalves, A.; Oxley, D.; Mohammed, H.; Turro, E.; Hemberger, M. Fgf and Esrrb Integrate Epigenetic and Transcriptional Networks That Regulate Self-Renewal of Trophoblast Stem Cells. Nat. Commun. 2015, 6, 7776.

(64) Amini, S.; Fathi, F.; Mobalegi, J.; Sofimajidpour, H.; Ghadimi, T. The Expressions of Stem Cell Markers: Oct4, Nanog, Sox2, Nucleostemin, Bmi, Zfx, Tcl1, Tbx3, Dppa4, and Esrrb in Bladder, Colon, and Prostate Cancer, and Certain Cancer Cell Lines. Anat. Cell. Biol. 2014, 47, 1-11.

(65) Madhu Krishna, B.; Chaudhary, S.; Mishra, D. R.; Naik, S. K.; Suklabaidya, S.; Adhya, A. K.; Mishra, S. K. Estrogen Receptor A Dependent Regulation of Estrogen Related Receptor B and Its Role in Cell Cycle in Breast Cancer. BMC Cancer 2018, 18, 607.

(66) Matsuda, T.; Irie, T.; Katsurabayashi, S.; Hayashi, Y.; Nagai, T.; Hamazaki, N.; Adefuin, A. M. D.; Miura, F.; Ito, T.; Kimura, H. et al. Pioneer Factor Neurod1 Rearranges Transcriptional and Epigenetic Profiles to Execute Microglia-Neuron Conversion. Neuron 2019, 101, 472-485 e477.

(67) Lei, K.; Li, W.; Huang, C.; Li, Y.; Alfason, L.; Zhao, H.; Miyagishi, M.; Wu, S.; Kasim, V. Neurogenic Differentiation Factor 1 Promotes Colorectal Cancer Cell Proliferation and Tumorigenesis by Suppressing the P53/P21 Axis. Cancer Sci. 2020, 111, 175-185.

(68) Osborne, J. K.; Larsen, J. E.; Shields, M. D.; Gonzales, J. X.; Shames, D. S.; Sato, M.; Kulkarni, A.; Wistuba, I. I.; Girard, L.; Minna, J. D. et al. Neurod1 Regulates Survival and Migration of Neuroendocrine Lung Carcinomas Via Signaling Molecules Trkb and Ncam. Proc. Natl. Acad. Sci. U. S. A. 2013, 110, 6524.

(69) Borromeo, Mark D.; Savage, Trisha K.; Kollipara, Rahul K.; He, M.; Augustyn, A.; Osborne, Jihan K.; Girard, L.; Minna, John D.; Gazdar, Adi F.; Cobb, Melanie H. et al. Ascl1 and Neurod1 Reveal Heterogeneity in Pulmonary Neuroendocrine Tumors and Regulate Distinct Genetic Programs. Cell Rep. 2016, 16, 1259-1272.

(70) Liu, H. T.; Liu, S.; Liu, L.; Ma, R. R.; Gao, P. Egr1-Mediated Transcription of LncrnaHnfla-As1 Promotes Cell-Cycle Progression in Gastric Cancer. Cancer Res. 2018, 78, 5877-5890.

(71) Feng, Z.; Wang, B. Long Non-Coding Rna Hnfla-As1 Promotes Cell Viability and Migration in Human Bladder Cancer. Oncol. Lett. 2018, 15, 4535-4540. 
(72) Hu, Y.; Wu, F.; Liu, Y.; Zhao, Q.; Tang, H. Dnmt1 Recruited by Ezh2-Mediated Silencing of Mir-484 Contributes to the Malignancy of Cervical Cancer Cells through Mmp14 and Hnf1a. Clin. Epigenetics 2019, 11, 186. 